\title{
ОСОБЛИВОСТІ ДЕРЖАВНОЇ ПОЛІТИКИ РЕГУЛЮВАННЯ МЕДИЧНИХ ПОСЛУГ В УКРАЇНІ
}

Aндріяш B.I., д-р наук 3 держ. упр., доцент, Інститут державного управління, Чорноморський національний університет імені Петра Могили м. Миколаїв, Україна.

Козлова Л.В., канд. наук 3 держ. упр, ст. викладач, Інститут державного управління, Чорноморський національний університет імені Петра Могили, м. Миколаїв, Україна.

Малікіна O.A., ст. викладач, Інститут державного управління, Чорноморський національний університет імені Петра Могили, м. Миколаїв, Україна.

Полякова О.А., магістр управління та адміністрування, провідний фахівець 3 методів розширення ринку збуту АТ «Київський вітамінний завод», м. Київ, Україна.

У статті досліджено теоретичні та практичні основи державної політики щзодо регулювання медичних послуг в Україні, що потребує підвищення рівня надання зазначених послуг та більш прозорої діяльності з надання таких послуг в умовах тривалого реформування в нашій краӥні. Авторами висвітлені особливості державного регулювання ринку медичних послуг, котрий перебуває y стані тривалого розвитку, котрий потребує жорсткого законодавчого регулювання для подальшого ефективного розвитку. Відзначено існування національних особливостей публічно-правового регулювання ринку медичних послуг в різних краӥнах, представлені 
практично діаметрально протилежними підходами і принципами. Здійснено аналіз державної політики України в галузі охорони здоров'я в якості організаційної та нормативної системи владних дій та управлінських рішень й основного регулятора здоров'я громадян. У статті сформульовано визначення державної політики регулювання медичних послуг з урахуванням специфіки медичної системи, окреслено проблеми в сфері організації ефективного державного регулювання медичних послуг та їх стандартизації, надані окремі рекомендації для створення ефективних механізмів державного впливу на ринок медичних послуг.

Ключові слова: державна політика, медичний ринок, медичні послуги, медична сфера, державне регулювання.

Постановка проблеми у загальному вигляді. Протягом тривалого періоду державна політика щодо охорони здоров'я спиралася на командно-адміністративну модель управління, котра виявилася застарілою, позакласовою, неефективною за сучасних умов, не передбачила ефективних механізмів державної політики та об' єктивного оцінювання реального стану системи охорони здоров'я в цілому й ринку медичних послуг зокрема, а також не здатною задовольнити зростаючі потреби галузі. Саме тому, вітчизняна система охорони здоров'я (далі - СО3) та ринок медичних послуг, на сьогодні, знаходяться в стані тривалого розвитку й потребують ефективної державної політики й жорсткого законодавчого регулювання. У зв'язку з цим не викликає сумніву важливість обговорення питань про межі медичного ринку та організаційноконтрольні державні функції в регламентації підприємницьких відносин з надання медичних послуг. хоча це не є показником відходу від приватного правового врегулювання, на котрому грунтується будь-яка підприємницька діяльність, це лише своєрідний пошук саме тієї «золотої середини» між державним та приватним правовим регулюванням - здійсненням переходу до ринку при активній державній підтримці й з регулюванням саме тих сфер, котрі зазвичай $\epsilon$ схильними до цього в країнах із розвиненою ринковою економікою. 
Аналіз останніх досліджень і публікацій. Розглядаючи стан наукової розробки питання становлення та розвитку ринку медичних послуг в Україні за умов тривалого реформування медичної галузі, варто зазначити, що у сучасних наукових колах дослідників цієї галузі небагато, але чітко простежується тенденція підвищення інтересу до цієї проблематики таких учених, як А. Аксюк, П. Воробйов, В. Новолодський, В. Пашков та інших. Дослідження проблем у межах теми спираються й на сучасні теоретико-методологічні розробки наступних дослідників: Р. Хеггліна, А. Вялкова, I. Миколайця та інших.

Метою статті $є$ проаналізувати особливості державної політики регулювання ринку медичних послуг в Україні.

Формулювання цілей статті (постановка завдання). В процесі дослідження були поставлені наступні завдання:

- розглянути основні особливості функціонування ринків медичних послуг;

- проаналізувати специфіку регулювання вітчизняного ринку медичних послуг;

- визначити особливості нормативно-правового регулювання ринків медичних послуг;

- окреслити основні напрями державної політики регулювання ринку медичних послуг.

Виклад основного матеріалу дослідження. На сьогодні, не зважаючи на задекларовану у вітчизняному законодавстві, безкоштовність надання допомоги державними медичними установами, ринок медпослуг нашої країни має досить велику наповненість й ще більшу базу для подальшого ефективного розвитку. Відповідно до даних державної служби статистики, витрати українців на медицину складають майже 4 \% бюджету вітчизняних домогосподарств (рис. 1 [22]).

Переважаючими у структурі вказаних витрат є покупка медичних товарів, в першу чергу ліків, витратних матеріалів та індивідуальних медичних препаратів. Крім того, досить часто саме купівля ліків здійснюється без попереднього відвідування лікаря, але на основі врахування попередніх призначень лікаря або власної ініціа- 


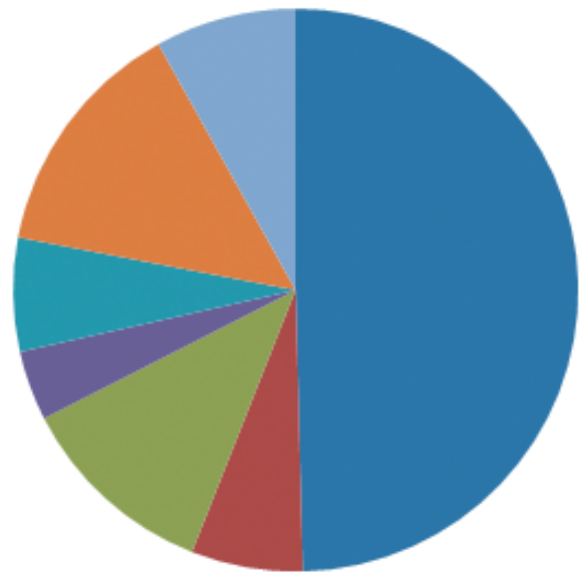

п Продукти харчування $49,6 \%$

- Одаг і вз уття $6,4 \%$

Комунальні платежі 11,5\%

- Охороназдоровя $4 \%$

- Транспорт і 3 в'яз ок 6,5\%

Іанше $13,9 \%$

- Неспоживчі витрати 8,1\%

Puc. 1. Частка витрат українців на медичні послуги, у \%

тиви пацієнтів. Держава бере участь в процесах державного врегулювання надання медпослуг шляхом видання необхідних нормативно-правових актів, котрі мають регламентувати вказану сферу, а також за допомогою здійснення контролю щодо дотримання задекларованих вимог у нормативно-правових актах (рис. 2).
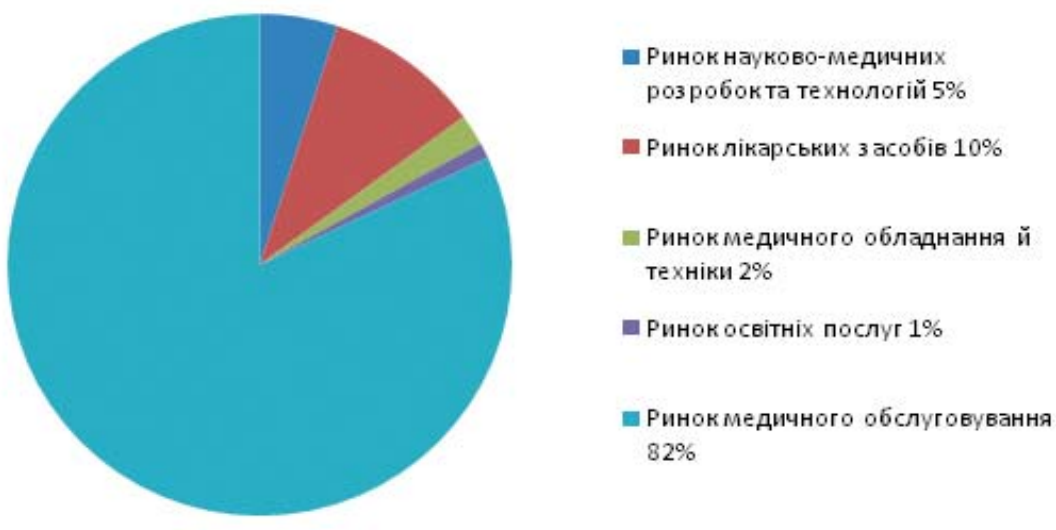

Puc. 2. Сегментація світового ринку медичних послуг $[4 ; 5 ; 6]$ 
Як наслідок, саме сукупність вказаних функцій формує межі «врегулювання ринку медпослуг, надаючи в усьому іншому свободу цивільно-правового врегулювання» [15, с. 127-128].

Варто наголосити, що ставлення до публічно-правового врегулювання ринків медпослуг та його сегментація $є$ неоднаковим у різних країнах світу. Зокрема, в США практично відійшли від державного втручання до сфери підприємницької діяльності в медицині й надають приватним лікарям право здійснювати самостійний, практично неврегульований розвиток. Такий стан речей сприймається дещо критично, оскільки, охорона здоров'я - є сферою, яка приносить державі неоціненні вигоди, здійснює зміцнення людських ресурсів, силою котрих, з часом, створюються всі матеріальні цінності та відбувається зміцнення національної економіки. Підтвердженням цього може слугувати й той факт, що згідно результатів проведеного опитування Commonwealth Fund, 82 \% американських громадян вважають свою СО3 такою, що потребує або ж грунтовного реформування, або ж повної перебудови [9].

Схожа ситуація є й в деяких європейських країнах, зокрема Німеччина, Франція, де громадяни також вимагають покращень у медичній сфері (рис. 3 [9]). Тому держава має бути зацікавлена в правовому забезпеченні медицини, в іiї регламентації.

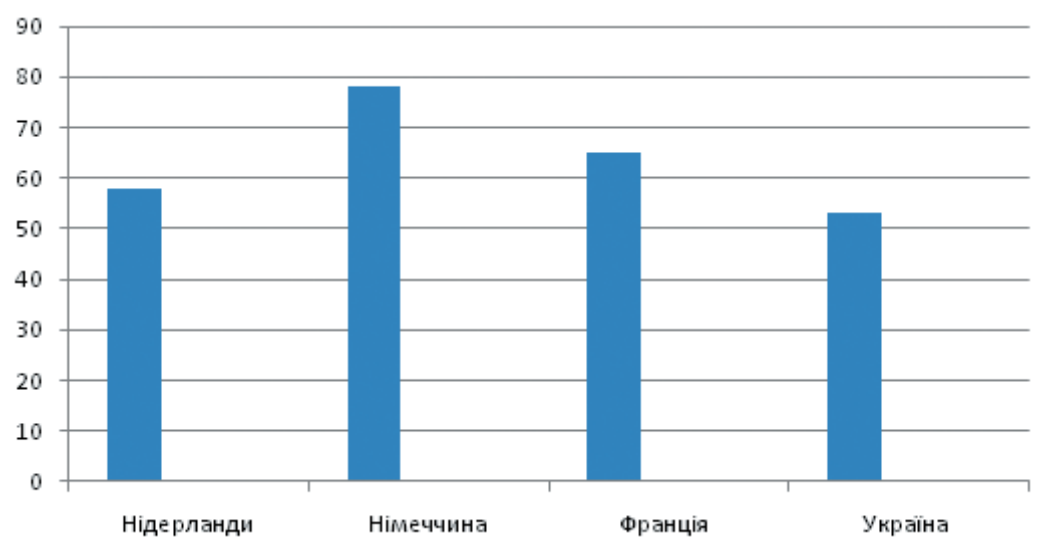

Puc. 3. Рівень громадян, на думку котрих необхідними є кардинальні зміни у системі охорони здоров'я, у \% 
Варто зауважити про існування протилежних моделей ринків, на котрих державі відведено першочергову роль. Здебільшого такі ринки допускають діяльність приватних лікарів, котрі працюють виключно за контрактом укладеним з урядом. Вказана модель $\epsilon$ моделлю лорда Беверіджа - засновника Національної служби охорони здоров'я Великобританії. Зазначену модель також не можемо вважати оптимальною, оскільки в ній відсутня здорова конкуренція й існування лише наданої медичної державою меддопомоги не може в повній мірі задовольнити існуючі потреби населення щодо забезпечення здоров'я за цілою низкою економічних причин. Вказані медичні ринки також існують в таких країнах, як Швеція, Італія тощо. Однак, наголосимо, що на сьогодні існують й більш оптимальні типи медичних ринків, котрі дотримуються оптимального поєднання «приватного та державного регулювання процесів надання медпослуг» [26] (табл. 1).

Таблиця 1

Джерела витрат на охорону здоров'я, у \% [12]

\begin{tabular}{|l|c|c|}
\hline \multicolumn{1}{|c|}{ Країна } & Державний сектор, \% & $\begin{array}{c}\text { Приватний сектор, } \\
\%\end{array}$ \\
\hline США & 44 & 56 \\
\hline Австрія & 66 & 34 \\
\hline Німеччина & 72,5 & 27,5 \\
\hline Японія & 73,8 & 26,2 \\
\hline Франція & 74 & 26 \\
\hline Канада & 75 & 25 \\
\hline Велика Британія & 85 & 15 \\
\hline
\end{tabular}

Варто зауважити, що дані наведені у таблиці $\epsilon$ підтвердженням точки зору тих дослідників, котрі наголошують, що існуючі проблеми в СО3, не можуть бути вирішеними без активного втручанні та участі держави [2; 23]. Такий підхід пояснюється тим, що СО3 - $є$ однієї із галузей соціальної 
сфери, в котрій перетинаються соціально-економічні, моральноетичні та політичні інтереси всього суспільства [10, с. 180]. Як наслідок, варто погодитися 3 думками деяких дослідників котрі наголошують, що державна політика щодо СО3 повинна бути наближеною до населення 3 одночасною передачею певної частини власних повноважень регіонам, однак процеси узгодження між попитом населення на медичну допомогу та пропозиціями СО3 повинні відбуватися централізовано. Тобто, для ефективної організації ринкових взаємовідносин у СО3 є необхідність створити ринок медпослуг у нашій державі [10, c. $129 ; 23$, с. 11]. Наголосимо, що в нашій державі протягом тривалого часу СО3 була виключно державною. Варто зауважити, що вказана система (а це була система Семашка) за певних умов працювала досить успішно [1, с. 475]. Однак, подальші зміни соціально-економічної ситуації в країні призвели до змін у СО3. На сьогодні частка приватного сектору в нашій державі зростає практично з кожним роком. Наприклад, у 2012 р. вона складала $1 \%$, а у 2019 р. більше $10 \%$ [25].

Отже, безсумнівною є необхідність співіснування в нашій країні приватної та державної медицини (за певних пропорцій), але за умов становлення ринку важливоює реалізація першої функції державного регулювання надання медпослуг - шляхом створення розгалуженої законодавчої опори підприємницьким взаємовідносинам. Для прикладу, державою, де приватна медицина є такою, що докладно регулюється, виступає Південно-Африканська Республіка (ПАР). Законодавчу базу ПАР скрупульозно розробляли протягом років (зокрема, закони про медичні страхові каси (1967р.), про здоров’я (1977 р.), про небезпечні речовини (1973 р.) та цілий ряд нормативноправових актів суто медичного призначення тощо), в результаті чого вдалося уникнути необхідності насаджувати державну медицину в тому обсязі, в котрому вона не була затребувана, й якщо із наявними запитами громадян ефективно справлялася приватна медицина. Як наслідок, приватна медицина почала задовольняти попит, а державна заповнювала потреби. В цілому держава контролює діяльність медичних працівників виключно за допомогою законодавчої 
регламентації відповідних взаємовідносин. Також, передбачається необхідність скрупульозного розроблення правової бази щодо таких напрямів публічно-правового регулювання, як ліцензування $[13$, c. 18].

Отже, ліцензування - $є$ одним із найважливіших напрямів державного регулювання надання медпослуг. Можливості здійснювати відповідного виду діяльності - $є$ об'єктом саме дозвільної системи (рис. 4). Таке право держава надає лише суб'єктам-підприємцям на підставі відповідного дозволу (ліцензіі) [7, c. 122].

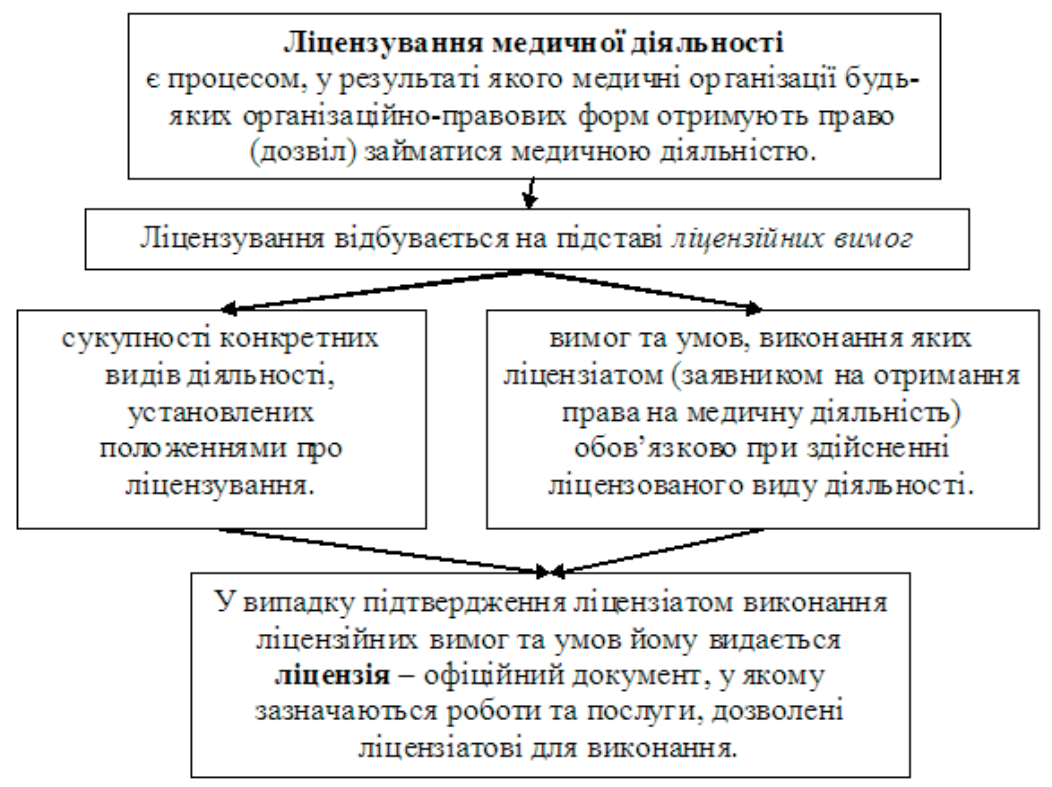

Puc. 4. Особливості ліцензування медичної діяльності

Наголосимо, що правовий інститут ліцензування в СО3 виник 3 необхідної умови існування ринкових взаємовідносин за нових економічних умов й з прийняттям закону України «Про державні фінансові гарантії надання медичних послуг та лікарських засобів» 
від 19 жовтня 2017 року [19]. Наголосимо, що СОЗ лише входила до ринкових взаємовідносин, де тільки рівні умови для всіх без виключення учасників вказаної системи й наявність добросовісної конкуренції повинні були отримати право на існування. Дещо пізніше на законодавчому рівні процедуру ліцензування було більш деталізовано, остаточного закріплення такі норми набули з 2003 року у Цивільному Кодексі України. У ЦкУ, на противагу раніше діючого цивільного законодавства, задля господарських товариств, а також інших виробничих кооперативів були встановлені правила, згідно яким вказані юридичні особи могли мати цивільні права та обов'язки щодо здійснення будь-яких видів діяльності, котра не була заборонена законом. Варто наголосити, що вказані нововведення й надали більшості комерційних організацій можливості змінювати власний профіль діяльності (не запитуючи на те дозволу й не змінюючи власних статутних документів), в той же час задля здійснення окремих видів діяльності виникла потреба у наявності спеціального дозволу - ліцензії [15, с. 128]. Такі заходи призвели до зміни в діяльності тих суб'єктів, котрі до цього здійснювали свою діяльність без належного дозволу. На сьогодні вже прийнято новий нормативно-правовий акт, котрий здійснює регулювання вказаної сфери. Варто зауважити, що, на жаль, по сьогодні практика врегулювання процесу ліцензування саме медичної сфери представлена цілою низкою нормативно-правових актів, виданих державними органами різних рівнів. Й питання щодо ліцензування також не $є$ внормованим, зокрема, 3 прийняттям нового закону більшість актів використовується здебільшого в тій частині, котра не суперечить новому закону.

Наголосимо, що порядок здійснення ліцензування передбачає наявність єдиних процесуально-технологічних механізмів, котрі враховуватимуть специфіку кожного виду діяльності; введення поняття «ліцензійних умов» та визначення необхідності їхного суворого дотримання. Однак, крім ліцензування, до сфери організаційно-контрольних функцій держави входять й такі правові інститути, як стандартизація й сертифікація, котрі на ринку медпослуг мають особливе значення, пов'язане 3 підвищеною 
небезпекою самої медичної діяльності задля життя й здоров'я споживачів [12, с. 11-12].

Вітчизняну СО3 вже практично переведено на страхову модель (рис. 4) [8].

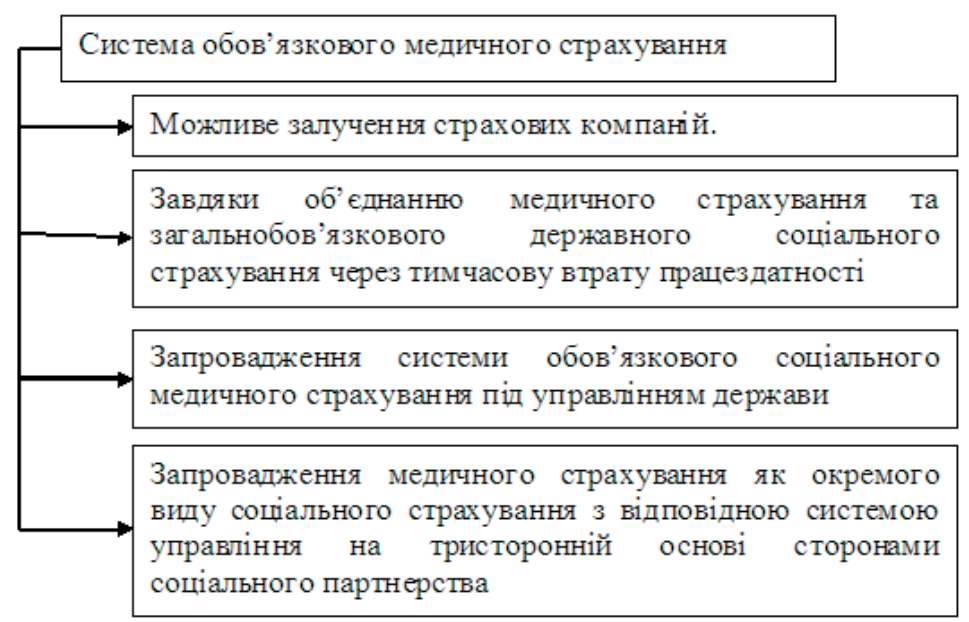

Puc. 5. Основні підходи щодо запровадження системи обов'язкового медичного страхування

Відповідно до наказу МОЗ України № 251 від 14.08 .98 р. сертифікатом фахівця в даному наказі вказано документи єдиного встановленого зразку, котрі здійснюють підтвердження відповідності підготовки фахівців у відповідності до вже встановлених освітніх стандартів [12, с. 10-11]. Сертифікатом фахівця засвідчується той факт, що його володар досяг певного встановленого рівня теоретичних знань, опанував практичні навички та уміння, котрі $\epsilon$ достатніми задля самостійного професійного здійснення медичної або фармацевтичної діяльності. Отримувати сертифікат потрібно кожні 5 років. Саме тому ефективне врегулювання процедур сертифікації фахівців медичної діяльності є вкрай актуальним на сьогодні [24, с. 2]. Зауважимо, що наявні складнощі щодо отримання 
сертифікатів, пов'язані, перш за все, $з$ відсутністю закріплення сертифікації фахівців медичної діяльності як обов'язкової. Й хоча необхідність законодавчого встановлення відповідних вимог до суб'єктів надання медпослуг є такими, що не викликають сумнівів, однак, регламентація умов якості самої медпослуги є найбільш актуальною в період становлення вітчизняної приватної медицини, а тому й пріоритет щодо регулювання повинен бути відданий саме ій $[16$, с. 10-11].

Крім того, в положеннях Закону України «Про захист прав споживачів» наголошено, що під час регулювання питань безпеки варто виходити 3 того, що безпека послуги має бути забезпечена стовідсотково, так само як безпека товарів чи робіт (ст. 7) [21]. Однак, зазначимо, що термін забезпечення безпеки вказаних послуг, на жаль, не прописано, хоча є зрозумілим, що безпека послуги має бути забезпечена виконавцем протягом всього періоду (чи процесу) надання такої послуги, а відповідальність за вчинену шкоду має наставати незважаючи на час іiї виникнення чи появи.

Схожий підхід (замовчування) використовують й під час врегулювання термінів майнової відповідальності за вчинену шкоду внаслідок недоліків послуг (ст. 16): щодо шкоди, котру завдано як наслідок наявності недоліків продукції (дефекти тощо) [21]. Ст. 1 (п. 16) вказаного закону взагалі вимагає від виробника послуг, на котрі законодавчі норми чи стандарти встановлюють відповідні вимоги, котрі здійснюють забезпечення безпеки життя, здоров'я, охорони навколишнього середовища та запобігають можливому заподіянню шкоди майна споживача, обов'язкову сертифікацію вказаних послуг [21].

Варто погодитися 3 деякими дослідниками, що Держстандарт, враховуючи той факт, що в законі йдеться про здійснення обов'язкової сертифікації потенційно небезпечних послуг задля життя та здоров'я, обрав 3 переліку послуги 3 найбільш ймовірними шкідливими наслідками й такі, що мають масовий характер (сертифікація послуг щодо ремонту електроапаратури, автотранспорту, туристичних й готельних послуг тощо) [14, с. 114; 16, с. 112]. Наголосимо, що такий підхід не викликає заперечень 
коли мова йде виключно про туристичні, готельні послуги чи навіть про рівень сервісу під час надання медпослуг. Але, якщо власне сама мед послуга, котра не підлягає уніфікації, з одного боку, й допускає чи припускає правомірність заподіяння шкоди здоров'ю, 3 іншого, застосування правил, котрі є придатними для початкового позбавлення шкідливих чи неякісних видів послуг, потребує певної обережності. Як наслідок, стандартизація, згідно визначення міжнародної організації зі стандартизації (ISO), - є діяльністю, зміст котрої є знаходженням рішення задля завдань, котрі повторюються, в сфері науки, техніки, економіки тощо, що спрямовані на досягнення оптимальних показників впорядкування певної галузі чи сфери.

Щодо питання сертифікації у СО3 то, на сьогодні, відсутне одностайне ставлення щодо необхідності розроблення й використання стандартів медпослуг. Одні з дослідників вважають, що використання встановлених стандартів ведення хворих $\epsilon$ некоректним [16, с. 123]. Інші відстоюють протилежну думку й наголошують, що стандарти - це єдино можливий спосіб визначити гарантований обсяг медичної допомоги пацієнту, котрий не може бути виражений інакше ніж виключно в описовій формі [16, с. 111]. Зокрема, в методичних рекомендаціях щодо оцінки якості медичної допомоги у сфері обов’язкового медичного страхування наголошено, що «дотримання чи порушення встановлених стандартів лікувального та діагностичного процесів саме по собі $\epsilon$ неоднозначним. Такі порушення можуть бути оцінені по-різному, за сприятливих результатів лікування, коли не так важливо, яким саме чином цей результат було досягнуто, й за несприятливих, коли оцінення змісту дій лікаря є ключовими» [11]. Варто погодитися 3 думкою I. Миколаєць, що лікар має повне право, й на нашу думку, навіть необхідність, на творчість, на створення та використання власних методів лікування, якщо результатом таких дій будуть виключно позитивні результати та динаміка [11].

Наголосимо, що на сьогодні не викликає сумнівів крайня необхідність та нагальність розроблення стандартів якості медичної допомоги. Вказаний процес $є$ досить актуальним та складним, що потребує поєднання в собі найбільш важливих форм, методів, 
способів лікування та вироблення основних стандартів щодо кожної окремо взятої мед послуги (рис. 6) [3, с. 101]. Відмінністю медичних стандартів $€$ те, що виконавець медпослуг обирає можливий варіант лікування спираючись на індивідуальний підхід до кожного із споживачів, але не зважаючи на таку ситуацію можливі форми стандартів, з котрих зможе обирати лікар, повинні бути сформовані.

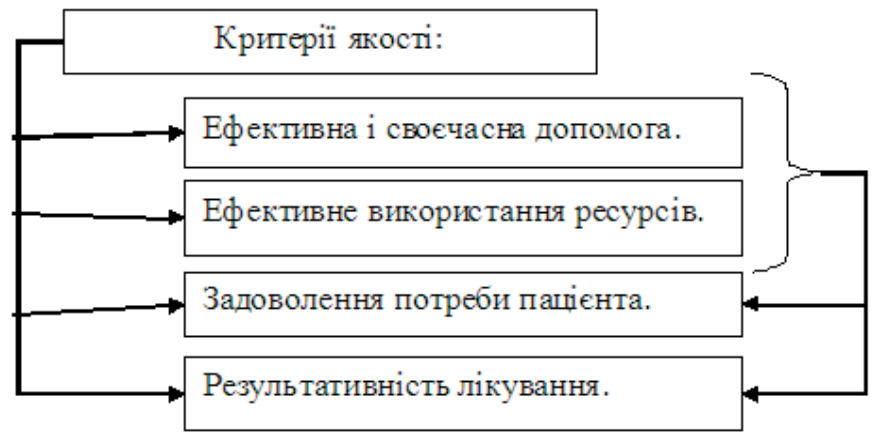

Puc. 6. Критерії якості медичних послуг

Крім того, на сьогодні відсутні встановлені стандарти медпослуг в повному обсязі, що стимулює до проведення широких досліджень із вказаного питання. Наприклад, А. Вялков, зараховує до основних об’єктів стандартизації охорони здоров'я й медпослуги, й якість медпослуг, й технологію виконання медпослуг самостійними об'єктами. Схожим є офіційний підхід на законодавчому рівні (Наказ Міністерство охорони здоров>я України від 21.03.2017 № 302 «Про затвердження Положення про групи експертів МОЗ України») [15, с. 128-129]. Однак, на думку А. Вялкова, саме медпослуги $€$ найважливішими та найскладнішими об’єктами. Дослідник стверджує, що нормативні документи мають містити як мінімальний необхідний набір, так й рекомендований набір вимог щодо тієї чи іншої медпослуги. Й саме мінімальний набір відповідних вимог повинен гарантувати всім громадянам рівні обсяги та якість медпослуг [16, с. 126]. 
Стандартизація підходів щодо лікування (медпослуг) - $\epsilon$ науковою, заснованою на статистичних дослідженнях діяльністю, котра полягає у знаходженні рішень для типових процесів, котрі дозволяють досягати оптимального ступеня впорядкованості щодо визначення предметної області; створюється для приведення великої кількості наявних видів станів та рішень щодо меншого числа типових зразків, в тому числі єдиних позицій щодо основних етапів боротьби з різноманітними захворюваннями, котрі характеризують весь курс лікування в цілому [16, с. 121]. На сьогодні, на думку деяких дослідників, система подібної стандартизації в нашій країні все ще не сформована, хоча потреба в тому більш ніж нагальна (рис. 7).

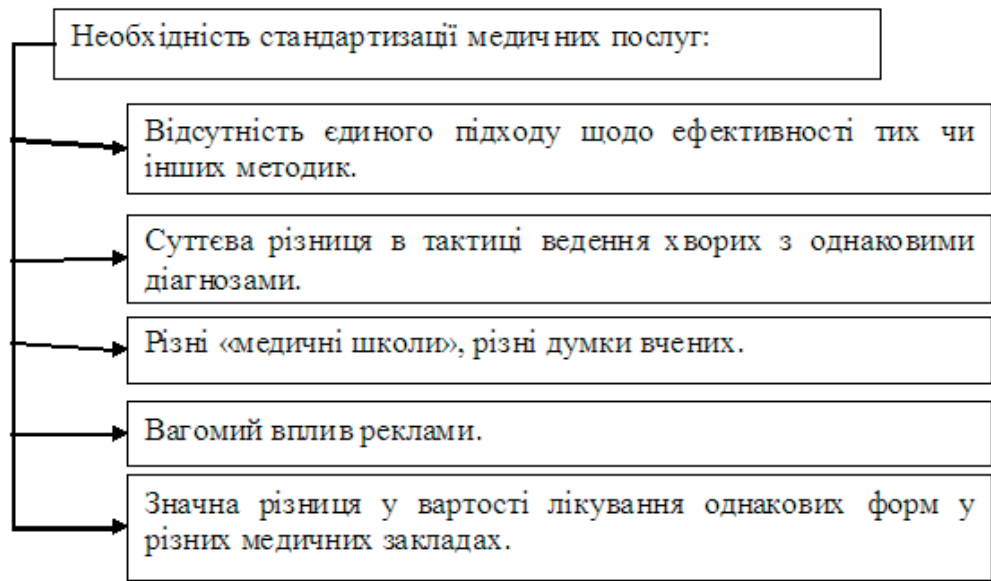

Puc. 7. Необхідність стандартизації медичних послуг

Загальноприйнято оцінювати медичну якість 3 трьох позицій (т. зв. Тріада Донабедіана): оцінювання ресурсів, оцінювання технологій $\mathrm{CO} 3$ (з відповідним використанням чи ні) й оцінювання ïх наслідків (чи результатів) [1, с. 475]. Оцінювання всіх вказаних компонентів якості проводиться шляхом порівняння з вже існуючими стандартами. Отже, можемо визначити основні три групи об'єктів оцінювання, а саме наявності: 
1) ресурсів (медичних і фармацевтичних закладів, інформаційних установ, кадрів та їхньої кваліфікація, матеріально-технічного оснащення);

2) процесів (лікувальних, діагностичних, профілактичних, peaбілітаційних, організаційних і медичних технологій);

3) наслідків втручань медичного характеру (результатів того чи іншого виду лікування різноманітних захворювань, ефективності, соціальних та економічних показників проведення будь-яких профілактичних чи інших заходів). Задля оцінювання ресурсів проводиться відповідне ліцензування й акредитація, а процеси та наслідки втручань медичного характеру - зіставляються із медичними стандартами діагностування й лікування хворих [14, с. 114-115].

Зазначимо, що в СО3 в якості стандартів можуть використовуватися лише ті технології, ефективність, безпечність та економічна доцільність котрих є доведеною, а стандартизація виступає в ролі реального способу впровадження доказової медицини в практику охорони здоров'я. Крім того, зважаючи на особливості вітчизняної медицини (поширення неспеціалізованих медичних установ в далеко розташованих один від одного населених пунктів) практично неможливо під час розроблення стандартів використовувати зарубіжний досвід, навіть найкращі практики. Варто наголосити, що найбільш вітчизняна СО3 в своїй основі є найбільш наближеною до існуючої СО3 США, де значний обсяг екстреної амбулаторної медичної допомоги надається не лікарями, й навіть не медичними сестрами, а виключно парамедичними працівниками. Такий підхід використовують й щодо викликів медичних працівників додому, тобто надання т. зв. «швидкої й невідкладної допомоги» [13, с. 18-19]. Крім того, надання парамедичної допомоги відбувається у відповідності до встановлених жорстких регламентів та стандартів, за яких фахівці-парамедики не лише займаються встановленням відповідного діагнозу чи стану пацієнта, але й діють суворо у межах обмеженого відповідними приписами у відповідності до виявленого чи встановленого синдрому. Щодо окремих видів медпослуг наявне суворе дотримання стандартів й надання медпослуг неспеціалістами, однак більшість 3 видів медичної допомоги є такими, що потребують 
професійного лікування у відповідності до індивідуальних особливостей пацієнта, котрі спираються на сукупність вже наявних знань у відповідного лікаря. Як наголошує І. Миколаєць, за будьяких умов мінімальні вимоги щодо медпослуг (чи то стандартів) повинні бути встановленні обов'язково [16, с. 134]. Лікар повинен хоча б знати, що саме йому дозволено й що саме він може робити, а що ж $є$ забороненим. Стандартні режими лікування також повинні ввібрати в себе наявні традиційні для вітчизняної медицини підходи щодо пацієнтів. Так звана «індивідуальність» лікування, тобто його можливі варіації, мають бути максимальною мірою покритими за допомогою багатофакторних стандартних форм, за допомогою котрих, під час розпізнавання захворювань, лікар повинен обрати лише свій, але в межах встановлених стандартів.

Медпослуги завжди мають відношення до певних захворювань й не можуть розглядатися окремо від них. Стандарти надання й виконання медпослуг також мають відповідати тому чи іншому встановленому діагнозу. Свого часу Р. Хегглін наголошував, що «основою кожної лікарської дії виступає встановлений діагноз», й саме тому формування стандартів має спиратися на наявний досвід у медичній сфері [11].

Отже, встановлення та дотримання хоча б мінімальних стандартів має бути вичерпним, аби сприяти встановленню правильної оцінки якості медпослуг, котрі було надано медичним працівником. Однак, 3 нормативно-правової точки зору, по сьогодні, вказане питання залишається практично не вирішеним [17]. Для фахівців-експертів буде досить сумнівними «переконливі» можливості лікарів на якомусь одному певному лікувальному прикладі стовідсотково підтвердити ефективність, безпечність та відсутність негативних тактичних й стратегічних наслідків використовуваного ними варіанту лікування. Вказане припущення на законодавчому рівні може сприйматися виконавцями в якості надання дозволу на певне недотримання чи ігнорування існуючих стандартів, що одночасно призведе до початку обвальної тривалої дестабілізації існуючої системи контролю, розвалу встановленого нормування й планування ресурсів, прогнозування результатів тощо. 
Актуальним щодо сфери медпослуг $€$ й встановлення відповідних термінів дії медичних стандартів. Наприклад, деякі дослідники вважають, що стандарт може вводитися на визначений термін, й організація-розробник, котра зацікавлена чи ініціює такий стандарт, змушена постійно відслідковувати наявні зміни задля підготовки нового нормативно-правового документу щодо стандартизації [17]. Такий підхід, на думку інших авторів, є досить доречним, оскільки медична сфера, котра для ефективного функціонування повинна слідкувати та вбирати в себе нові технології, методи лікування, потребує не лише розроблення та прийняття стандартів, але й їхнього постійного вдосконалення [16, c. 211].

Отже, сертифікація медпослуг також має двоякий зміст. Вищевказані правила, й більшість нормативно-правових положень та норм щодо охорони здоров'я свідчать про можливість отримання ліцензії, так й про можливість надання медпослуг населенню на певній платній основі лише за наявності сертифіката з відповідно встановленими стандартами. Варто зауважити, що норми Закону України «Про стандартизацію», котрий у переліку послуг, що $\epsilon$ обов'язковими для сертифікації, не містить конкретних вказівок щодо медпослуг, ні самі т. зв. «встановлені стандарти», котрі $є$ відсутніми по сьогодні, не містять жодних відповідей щодо вказаного питання [20].

Однак, медицина, будучи одним із видів суспільно важливої діяльності, повинна в обов'язковому порядку мати державні стандарти щодо надання необхідної медичної допомоги, які не будуть «розкидані» по різним нормативно-правовим актам, а будуть зібрані воєдино з відповідною класифікацією задля забезпечення інтересів споживачів медпослуг. Крім того, відповідні медпослуги повинні бути включені до переліку послуг, котрий підлягатиме обов'язковій сертифікації з метою привести до відповідності нормативно-правові акти, а також унормувати завеликий у вітчизняній медицині перелік життєво необхідних медпослуг. Вказане повинно забезпечити формування відповідних стандартів в медичній галузі й стимулювати формування та функціонування більш суворої системи контролю за їхнім дотриманням. 
Цікавим є й той факт, що у відповідності до вищевказаних Основ надання платних медпослуг населенню медичні установи здійснюють лише при наявності у них відповідного сертифікату й ліцензії на обраний ними вид діяльності чи профілю. Однак, вимога щодо обов'язковості сертифікації медпослуг все ще відсутня. Як наслідок, відсутність єдиної сертифікації призводить до того, що жодназ установ не має права надавати платні медпослуги. Законодавці грунтуються на тому, що правові норми, котрі є визначальними умовами публічних договорів, можуть встановлюватися не лише законодавчими нормами, але й постановами уряду, котрі підтверджуватимуть діючі правила $[15$, c. 130$]$.

Висновки. Таким чином, можемо стверджувати, що сертифікації на ринку медпослуг повинні підлягати різноманітні категорії: фахівці 3 вищою та середньою професійною освітою, надання медпослуг, а також юридичні особи й приватні підприємці, котрі мають наміри здійснювати медичну діяльність на тому чи іншому медичному ринку. Як наслідок, вказані об'єкти сертифікації (обов'язково медпослуги) повинні бути включеними Урядом України до переліку робіт й послуг, котрі є обов'язковими для проходження сертифікації. Такий підхід дозволить підвищити ефективність контролю щодо якості медичної допомоги під час здійснення приватної підприємницької діяльності медичними організаціями будь-якої форми власності. На сьогодні, на жаль, жодна із вказаних форм сертифікації належним чином на законодавчому рівні не оформлена. Всі наявні види медпослуг мають містити мінімальні вимоги (обов'язкові, рекомендовані) щодо їхнього здійснення, оформлюватися відповідно до стандартів, котрі є прийнятими навіть на певний термін. Саме тому подальші дії лікарів можуть грунтуватися на професійних знаннях та положеннях медичної спеціальності та не мають їм суперечити.

Отже, державна політика повинна бути спрямована на здійснення якісної та ефективної реалізації медпослуг, реформування котрих розпочалося у 2017 р. ознаменувавшись новими підходами щодо ліцензування медичних послуг, започаткуванням страхової медицини, розширенням переліку та підвищенням якості надання медичних послуг. такі заходи державної політики повинні стати 
одним із реальних шляхів виходу СО3 та медичних ринків із наявної затяжної, масштабної кризи, оновленням не лише медичної, але й всієї соціально-гуманітарної сфери. Крім того це також обумовлено й тим, що рівень показників здоров’я громадян - це узагальнююча характеристика рівня й якості життя населення, індекс соціального, культурного й економічного розвитку вітчизняного суспільства в цілому. Ефективність державної політики в сфері охорони здоров'я також здійснює вплив й на рівень національної безпеки нашої держави.

\section{Стаття надійшла до редакції: 23.05.20}

\section{PECULIARITIES OF STATE POLICY OF REGULATION OF MEDICAL SERVICES IN UKRAINE}

Victoria Andriyash, Doctor of Science in Public Administration, Associate Professor of the Department of Public Administration and Administration Institute of Public Administration Black Sea National University of Petro Mohyla Mykolaiv, Ukraine.

Kozlova Liudmyla, Associated Professor $\mathrm{PhD}$ in Public Administration of the Institute of Public Administration of the Black Sea National Petro Mohyla University, Mykolaiv, Ukraine.

Oksana Malikina, Senior Lecturer in the Department of Public Administration and administration Institute of Public Administration Black Sea National University of Petro Mohyla Mykolaiv, Ukraine.

Elena Polyakova, Master of Public Administration Institute of Public Administration Black Sea National University of Petro Mohyla Mykolaiv, Ukraine.

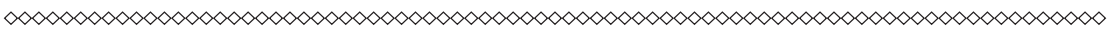

The article emphasized that for a long period the state health policy relied on a command-administrative model of management, which turned 
out to be outdated, out-of-class, ineffective under the current conditions, did not provide for effective mechanisms of state policy and an objective assessment of the real state of the health care system. and the health care market in particular, as well as not being able to meet the growing needs of the industry. In addition, it has been established that the domestic health care system and the healthcare market are in a state of long-term development and require effective public policy and stringent legislative regulation.

The theoretical and practical bases of the state policy on the regulation of medical services in Ukraine are investigated. The authors highlight the peculiarities of state regulation of the medical services market, which is in a state of long-term development, which needs rigid legislative regulation for further effective development.

The existence of national peculiarities of public-legal regulation of the market of medical services in different countries is noted, and practically diametrically opposite approaches and principles are presented. The analysis of the state policy of Ukraine in the field of health care as an organizational and normative system of power actions and management decisions and the main regulator of public health.

The article defines the state policy of regulation of medical services, taking into account the specifics of the medical system, outlines the problems in the field of organization of effective state regulation of medical services and their standardization, provides some recommendations for creating effective mechanisms of state influence on the market of medical services.

The article shows that the level of indicators of public health is a general characteristic of the level and quality of life of the population, an index of social, cultural and economic development of the national society as a whole. The effectiveness of public health policy also affects the level of national security of our country.

Keywords: state policy, medical market, medical services, medical sphere, state regulation.

Received: 23.05 .20 


\section{References}

1. Andriiash, V., Malikina, O. \& Poliakova, O. (2019) Mizhnarodnyi dosvid finansuvannia reform u sferi okhorony zdorovia [International experience in financing health care reform]. Publichne upravlinnia ta rehionalnyi rozvytok, 5, 474-492 [in Ukrainian].

2. Antoniuk, S., Radysh, Ya. (2005). Derzhavne rehuliuvannia rozvytku pryvatnoho sektora $\mathrm{v}$ okhoroni zdorovia Ukrainy (na prykladi nadannia naselenniu stomatolohichnoi dopomohy) [State regulation of private sector development in health care of Ukraine (for example rendering dental care to the population)]. Visnyk NADU, 2, 147-152 [in Ukrainian].

3. Chernenko, V.H. (2002). Dosvid krain Yevropy u finansuvanni haluzi okhorony zdorovia. Uroky dlia Ukrainy [European experience in health care financing. Lessons for Ukraine]. Kyiv. Akadempres [in Ukrainian].

4. Deloitte (2019). www.deloitte.com. Retrieved from http:www.deloitte. $\mathrm{com} / \mathrm{kz} / \mathrm{ru} / \mathrm{pages} /$ life-sciences-and-healthcare/articles/2017/global-health-caresector-outlook.html [in English].

5. DTTL Global Life Science sand Health Care (LSHC) Industry Group analysis of The World Health Organization Global Health Expenditure data base (2018). apps.who.int. Retrieved from http:apps.who.int/nha/database [in English].

6. Haponova, E.O. (2019). Suchasni tendentsii rozvytku svitovoho rynku medychnykh posluh [Current trends in the world market of medical services] Dysert. na zd. nauk. stup. kan. ekon. nauk za spetsialnistiu 08.00.02 svitove hospodarstvo i mizhnarodni ekonomichni vidnosyny (Ekonomichni nauky). Kharkiv, Kharkivskyi natsionalnyi universytet imeni V. Karazina [in Ukrainian].

7. Klymenko, O.V. (2016). Derzhavne rehuliuvannia medychnoi diialnosti v Ukraini: heneza ta tendentsii rozvytku [State regulation of medical activity in Ukraine: genesis and development trends]. Dys. dokt. yur. nauk : 25.00.01. Kyiv [in Ukrainian].

8. Kotova, S.S. (2011). Strakhova medytsyna i medychne strakhuvannia: neobkhidnist, sut, sposoby vprovadzhennia v Ukraini [Insurance medicine and medical insurance: necessity, essence, methods of implementation in Ukraine]. Naukovyi visnyk Poltavskoho universytetu ekonomiky i torhivli. Seriia : Ekonomichni nauky, 4(1). Retrieved from http://nbuv.gov.ua/UJRN_8 [in Ukrainian]. 
9. Medychna reforma: minimum derzhavy. Likarni pryvatyzuvaty, likariv zvilnyty [Medical reform: the state minimum. Hospitals privatize, doctors release]. texty.org.ua. Retrieved from http: https://texty.org.ua/articles/29767/ Medychna [in Ukrainian].

10. Miezentseva N., Buravlov L. \& Radyshch Ya. (2008). Pravove rehuliuvannia pryvatnoho sektora $\mathrm{v}$ okhoroni zdorovia Ukrainy: stan i perspektyvy rozvytku [Legal regulation of the private sector in health care in Ukraine: the state and prospects of development]. Medychne pravo Ukrainy: pravovyi status patsiientiv $\mathrm{v}$ Ukraini ta yoho zakonodavche zabezpechennia (henezys, rozvytok, problemy i perspektyvy vdoskonalennia). Materialy II Vseukrainskoi naukovo-praktychnoi konferentsii 17-18.04.2008 r. (pp. 179185). Lviv [in Ukrainian].

11. Mykolaiets, I.V. (2016). Derzhavne rehuliuvannia nadannia medychnykh posluh, yak skladova sotsialnoho zakhystu naselennia [State regulation of the provision of medical services as a component of social protection of the population] Derzhavne upravlinnia: udoskonalennia ta rozvytok, 10 . Retrieved from http: www.dy.nayka.com.ua [in Ukrainian].

12. Mykolaiets, I.V. (2017). Mekhanizm derzhavnoho rehuliuvannia orhanizatsiino-ekonomichnoho zabezpechennia nadannia yakisnykh medychnykh posluh [The mechanism of state regulation of organizational and economic provision of quality medical services]. Nauka i studia, 15 (176), 9-19 [in Ukrainian].

13. Mykolaiets, I.V. (2017). Metody derzhavnoho rehuliuvannia nadannia medychnykh posluh ta upravlinnia yakistiu [Methods of state regulation of medical services and quality management]. Publichne upravlinnia ta mytne administruvannia, 2 (17), 17-21 [in Ukrainian].

14. Mykolaiets, I.V. (2017). Stanovlennia ta rozvytok derzhavnoho rehuliuvannia nadannia medychnykh posluh [Formation and development of state regulation of medical services]. Investytsii: praktyka ta dosvid, 23, 113116 [in Ukrainian].

15. Mykolaiets, I.V. (2017). Vplyv derzhavnoho rehuliuvannia na formuvannia modeli sotsialnoho zakhystu naselennia [Influence of state regulation on formation of model of social protection of population]. Investytsii: praktyka ta dosvid, 24, 127-130 [in Ukrainian]. 
16. Mykolaiets, I.V. (2018). Mekhanizmy derzhavnoho rehuliuvannia nadannia medychnykh posluh $\mathrm{v}$ Ukraini [Mechanisms of state regulation of medical services in Ukraine]. Dys. kand. nauk z derzh. upr. : 25.00.02; Mizhrehion. Akad. upr. personalom. Kyiv [in Ukrainian].

17. Pashkov, V. M. (2015). Reforma okhorony zdorovia vid Uriadu: arhumenty za ta proty [Government Health Reform: Pros and Cons]. Shchotyzhnevyk APTEKA. 32(1003) vid 24.08.2015 r. (V. 6-7). Retrieved from http: http://www.apteka.ua [in Ukrainian].

18. Pidaiev, A., Vozianov, O., Moskalenko, V. \& Ponomarenko, V. etc. (2010). Panorama okhorony zdorovia naselennia Ukrainy [Panorama of public health in Ukraine]. Kyiv, Vydavnytstvo «Zdorovia» [in Ukrainian].

19. Pro derzhavni finansovi harantii medychnoho obsluhovuvannia naselennia Zakon Ukrainy No 524-IX vid 04.03.2020 r. [About the state financial guarantees of health care of the population]. zakon.rada.gov.ua. Retrieved from http: zakon.rada.gov.ua/laws/show/2168-19 [in Ukrainian].

20. Pro standartyzatsiiu Zakon Ukrainy No 124-VIII vid 15.01.2015 r. [About standardization]. Vidomosti Verkhovnoi Rady, 31, st. 1058 [in Ukrainian].

21. Pro zakhyst prav spozhyvachiv (1991) Zakon Ukrainy No 1024KhII vid 12.05.91 r. iz zminamy ta dopovnenniamy [On consumer protection]. Vidomosti Verkhovnoi Rady, 30, st. 379 [in Ukrainian].

22. Rynok medychnykh posluh v Ukraini: ye prostir dlia rozvytku (2020) [Healthcare market in Ukraine: there is room for development]. pro-consulting. ua. Retrieved from http:pro-consulting.ua/ua/pressroom/rynok-medicinskihuslug-v-ukraine-est-prostranstvo-dlya-razvitiya [in Ukrainian].

23. Shutov, M.M. (2004). Orhanizatsiino-ekonomichnyi mekhanizm rozvytku systemy okhorony zdorovia $\mathrm{u}$ rehioni [Organizational and economic mechanism of development of health care system in the region]. Avtoref. dys. d.e.n.: Instytut ekonomiko-pravovykh doslidzhen NAN Ukrainy. Donetsk [in Ukrainian].

24. Tekhnolohiia upravlinnia zakladom okhorony zdorovia : daidzhest [Healthcare facility management technology: a digest] (2017). Dnipropetrovsk, V. 1, 17 [in Ukrainian].

25. Yakist yaka po kysheni nebahatom analiz rynku medychnykh posluh $\mathrm{v}$ Ukraini [Quality is affordable for few analysis of the medical services market in Ukraine]. vezha.net.ua. Retrieved from http:vezha.net.ua/suspilstvo/yakist-yaka-pokisheni-nebagatom-analiz-rinku-medichnix-poslug-v-ukrayini [in Ukrainian]. 
26. Vsi ofitsiini dokumenty $\mathrm{z}$ medychnoi reformy $\mathrm{v}$ Ukraini stanom na 01.07.2018. [All official documents on medical reform in Ukraine as of 01.07.2018]. www.sunrisemy.com. Retrieved from https://www.sunrisemy.com/ vsi-oficijni-dokumenti-zmedichno-v-ukra\%D1\%97ni-stanom-na-01-07-2018 [in Ukrainian].

\section{Відомості про авторів / Information about the Authors}

Андріяш Вікторія Іванівна: Інститут державного управління, Чорноморський національний університет імені Петра Могили вул. 68 десантників 10, Миколаїв, 54003, Україна.

Victoria Andriyash: Institute of Public Administration Black Sea National University of Petro Mohyla: 68 Desantnykiv str. 10, Mykolaiv, 54003, Ukraine.

\section{ORCID. ORG/ 0000-0001-5294-7456}

\section{E-mail: andriyash_v2017@ukr.net}

Козлова Людмила Василівна: Чорноморський національний університет імені Петра Могили: вул. 68 десантників 10, м. Миколаїв, 54003, Україна.

Liudmyla Kozlova: Black Sea National University of Petro Mohyla: 68 Desantnykiv str. 10, Mykolaiv, 54003, Ukraine.

\section{ORCID. ORG./ 0000-0003-4808-6846}

\section{E-mail: kozlovalife@ukr.net}

Малікіна Оксана Анатоліївна: Інститут державного управління, Чорноморський національний університет імені Петра Могили вул. 68 десантників 10, Миколаїв, 54003, Україна.

Malikina Oksana: Institute of Public Administration Black Sea National University of Petro Mohyla: 68 Desantnykiv str. 10, Mykolaiv, 54003, Ukraine. 
ORCID.ORG/ 0000-0002-3377-3443

E-mail: oksi_mal@ukr.net

Полякова Олена Анатоліївна: АТ «Київський вітамінний завод», вул. Кропилівська 38, Київ, 02000, Україна.

Elena Polyakova: AP «Kyiv Vitamin Plant», 38 Kropylivska Street, Kyiv, 02000, Ukraine

ORCID. ORG/ 0000-0002-6396-3299

E-mail: polyakova.69@ukr.net 